\title{
Ormeloxifene versus Tranexamic acid in dysfunctional uterine bleeding comparative evaluation
}

\author{
Kaliki Hymavathi*, Malini Devi Gottipati, Prasuna, Sudha V.
}

Department of Obstetrics and Gynecology, NMCH, Nellore, Andhra Pradesh, India

Received: 22 November 2017

Accepted: 22 December 2017

\section{* Correspondence:}

Dr. Kaliki Hymavathi,

E-mail: drhymakrreddy@yahoo.co.in

Copyright: ( ) the author(s), publisher and licensee Medip Academy. This is an open-access article distributed under the terms of the Creative Commons Attribution Non-Commercial License, which permits unrestricted non-commercial use, distribution, and reproduction in any medium, provided the original work is properly cited.

\begin{abstract}
Background: Dysfunctional Uterine bleeding (DUB) is the most common cause of abnormal uterine bleeding (AUB). Medical therapy being the first line of management, an ideal drug should be able to block the estrogenic effects on the Endometrium without interfering with its beneficial effects on other tissues. Both Ormeloxifene - a selective estrogen receptor modulator (SERM) and Tranexamic acid-an anti fibrinolytic inhibitor is important in the treatment of DUB. The aim of this study is to assess the efficacy and safety of Ormeloxifene v/s Tranexamic acid in the treatment of DUB.

Methods: This is a prospective double blind study conducted for 2 years in 200 women presenting with DUB attending to the Gynaecology outpatient department (OPD) of Narayana Medical College and Hospital, Nellore, AP, India. Two hundred women presenting with DUB were recruited into this study (after fulfilling inclusion and exclusion criteria) with informed consent and randomly divided into two equal groups (Group-A and Group-B) after obtaining college ethical committee approval.

Results: The reduction in the mean pictorial blood loss assessment chart (PBAC) score with Ormeloxifene (from 278 to 97.6) was significantly more than that of Tranexamic acid (from 261 to 134.5) at six months (p <0.0001). The rise in Hemoglobin concentration $(8.4 \mathrm{~g} \%$ to $11.15 \mathrm{~g} \%$ vs. 8.5 to $9.7 \mathrm{gm} \%$; p < 0.008$)$ and reduction in Endometrial thickness (from $10.57 \mathrm{~mm}$ to $6.5 \mathrm{~mm} \mathrm{v} / \mathrm{s} 9.96 \mathrm{~mm}$ to $7.24 \mathrm{~mm} \mathrm{p}<0.0001$ ) were also significantly more with Ormeloxifene than with Tranexamic acid. Relief from dysmenorrhoea and subjective improvement were also found to be considerable with Ormeloxifene.

Conclusions: Both Ormeloxifene and Tranexamic acid can be considered for DUB treatment but Ormeloxifene is found to be superior to Tranexamic acid in various aspects.
\end{abstract}

Keywords: Dysfunctional uterine bleeding, Ormeloxifene, Tranexamic acid

\section{INTRODUCTION}

Menstrual disorders are the most common gynecological conditions resulting in hospital referrals. Approximately $20-30 \%$ of women (among 35-50 yrs of age) seek medical help for heavy menstrual bleeding (HMB) resulting in anaemia affecting their physical, social and emotional quality of life. ${ }^{1}$ The approach to management is to ensure general well being and improve quality of life in addition to control of the bleeding. Medical therapy is the first line of management for DUB. Various drugs available for medical treatment are non-steroidal anti-inflammatory drugs, progestogens, combined estrogen and progesterone pills, Danazol, GnRH analogues and hormone releasing intrauterine devices with their notable advantages and disadvantages. $^{2}$

The ideal therapy should be with a drug that can block the action of Oestrogen on Endometrium but not its beneficial effects on other tissues. ${ }^{3}$ SERMs are drugs that act in specific ways at estrogen receptor sites in different tissues. The molecular basis of the SERM activity involves 
binding of the ligand SERM to the oestrogen receptor (ER), thus causing conformational changes which facilitate interactions with the co activator or the co repressor proteins, and subsequently initiating or suppressing the transcription of the target genes. The SERM activity is intrinsic to each ER ligand, which accomplishes its unique profile by specific interactions in the target cell, leading to tissue selective actions. ${ }^{4}$ Ormeloxifene is an optimally designed SERM with varied tissue response. It is indicated for the treatment of DUB at any age because of the ease of administration, cost effectiveness, and lesser side effects. The additional benefit of this drug is that it decreases total and LDL cholesterol by about $20-30 \%$ which is a favourable point in relatively elder women. ${ }^{3,5}$ Women with HMB have been found to have elevated endometrial levels of Plasminogen to cause local fibrin degradation without changing blood coagulation parameters. ${ }^{6}$

\section{METHODS}

This is a prospective double-blind study conducted for 2 years in 200 women presenting with DUB attending to the Gynecology outpatient department (OPD) of Narayana Medical College and Hospital, Nellore, AP, India.

Women aged more than 40years were also recruited into this study provided an endometrial biopsy done in the last six months with a negative report for malignancy.

\section{Exclusion criteria}

- Pregnancy.

- Systemic and endocrine disorders.

- Women who delivered recently (within 6 months).

- Severe bleeding requiring parenteral (I.V.) Tranexamic acid injections.

Institutional ethical committee approval and Informed consent of the recruited population was taken.

A detailed history [demographic, complaints, past obstetric (medical and surgical)] and clinical examination was done. Apart from the routine blood and urine tests special investigations with regard to present complaint like Thyroid profile, coagulation profile and pelvic ultrasound (to measure ET and to look for any other pelvic pathology) were done to rule out any organic cause for abnormal uterine bleeding so as to confirm the diagnosis of DUB.

Subjects were asked to maintain a menstrual diary recording the days of bleeding, number of sanitary pads used, degree of soiling of each pad, number and size of clots passed, episodes of bleeding, the presence of menstrual cramps and other symptoms experienced. PABC Scoring was done accordingly to assess menstrual blood loss 3 (Table 1). A PBAC score $\geq 100$ indicates a menstrual blood loss $\geq 80 \mathrm{ml}$ and is considered diagnostic of menorrhagia. ${ }^{7}$

Table 1: PBAC scoring.

\begin{tabular}{|ll|}
\hline Pads & Score \\
\hline Lightly soiled & 1 \\
\hline Moderately soiled & 5 \\
\hline Fully soaked & 20 \\
\hline Clots & \\
\hline Small (Smaller than a rupee coin) & 1 \\
\hline Large (Larger than a rupee coin) & 5 \\
\hline
\end{tabular}

Women were randomly allocated to two groups of 100 each (Group A and Group B). A clinical nurse assigned the recruited subjects to either of the groups to administer the particular medication (Ormeloxifene/Tranexamic acid). The treating physician and subjects were blinded about the medication. Group A was given Ormeloxifene tablet $60 \mathrm{mg}$ twice a week for 12 weeks followed by $60 \mathrm{mg}$ once a week for next 12 weeks. Group B received Tab. Tranexamic acid from $1500 \mathrm{mg}$ to $4 \mathrm{gm} /$ day for 4 to 7 days of menstrual cycle from the first day onwards. Follow up was done at 2, 4 and 6 months. At each visit a detailed menstrual history was taken, PBAC score was calculated, Hemoglobin concentration and ET were measured. Subjective improvement and any side effects experienced were also noted and are taken as outcome measures. All parameters were presented as mean and were analysed using the student $\mathrm{t}$ test. Statistical significance was taken at $\mathrm{p} \leq 0.05$.

\section{RESULTS}

Since it was decided that the drugs' efficacy has to be evaluated without bias precautions were taken in the recruitment and division of groups to match in mean age, parity, pre-treatment mean PBAC scores, mean Hemoglobin level and ET (Table 2).

Table 2: Clinical profile before therapy.

\begin{tabular}{|lll|}
\hline $\begin{array}{l}\text { Clinical } \\
\text { parameters }\end{array}$ & $\begin{array}{l}\text { Group A } \\
\text { (Ormeloxifene) } \\
\mathrm{n}=\mathbf{1 0 0}\end{array}$ & $\begin{array}{l}\text { Group B } \\
\text { (Tranexamic } \\
\text { acid) } \mathbf{n = 1 0 0}\end{array}$ \\
\hline Mean age (years) & 39.45 & 39.83 \\
\hline Mean parity & 2.8 & 2.6 \\
\hline Mean PBAC & 278 & 261 \\
\hline Mean Hb (gm\%) & 8.4 & 8.5 \\
\hline Mean ET (mm) & 10.57 & 9.96 \\
\hline
\end{tabular}

The mean pre-treatment PBAC scores with Ormeloxifene (278.47) were found to be reduced to $152.29,84.07$ and 54.6 after 2, 4 and 6 months respectively with a significant $\mathrm{p}$ value. The mean pre-treatment PBAC score with Tranexamic acid 261.11 reduced to $173,133.35$ and 96.90 after 2, 4 and 6 months of therapy $(\mathrm{p}<0.0001)$. Thus $77 \%$ of women had a PBAC score $<100$ at 6 months follow up with Ormeloxifene as compared to only $42 \%$ with Tranexamic acid. 
The mean Endometrial thickness was significantly reduced from $10.57 \mathrm{~mm}$ to $6.5 \mathrm{~mm}$ after 6 months of therapy with Ormeloxifene $(\mathrm{p}<0.001)$ whereas with Tranexamic acid the corresponding figures are $9.96 \mathrm{~mm}$ and $7.24 \mathrm{~mm}(\mathrm{p}<0.001)$.

The pre-treatment mean Hemoglobin concentration in group A was raised from $8.7 \mathrm{gm} \%$ to $11.15 \mathrm{gm} \%$ at 6 months with Ormeloxifene $(\mathrm{p}<0.0001)$, whereas with Tranexamic acid the figures were $8.68 \mathrm{gm} \%$ and $9.7 \mathrm{gm} \%$ $(\mathrm{p}<0.0001)$.

Dysmenorrhoea before treatment was noted in $28 \%$ women in group A and $30 \%$ in group B. At the end of the treatment only $6 \%$ women in group A were still complaining of dysmenorrhoea compared to $14 \%$ in group B. Subjective improvement of symptoms was noted in $88 \%$ and $56 \%$ of groups $\mathrm{A}$ and $\mathrm{B}$ respectively (Table 3).

Table 3: Clinical profile after therapy.

\begin{tabular}{|c|c|c|c|}
\hline PBAC scores & Group A & Group B & p-value \\
\hline At 2 months & 152.29 & 173.89 & $<0.01$ \\
\hline At 4 months & 84.07 & 133.35 & $<0.001$ \\
\hline At 6 months & 54.6 & 96.9 & $<0.001$ \\
\hline $\begin{array}{l}\text { Mean PBAC } \\
\text { (after } 6 \text { months) }\end{array}$ & 97.6 & 134.5 & $<0.001$ \\
\hline $\mathrm{ET}(\mathrm{mm})$ & 6.5 & 7.24 & $<0.05$ \\
\hline Haemoglobin (gm\%) & 11.15 & 9.7 & $<0.05$ \\
\hline Dysmenorrhoea & $6 \%$ & $14 \%$ & $<0.05$ \\
\hline \multicolumn{4}{|c|}{ Subjective feeling $(\%)$} \\
\hline No improvement & 6 & 14 & \\
\hline Mild improvement & 6 & 30 & \\
\hline Marked improvement & 88 & 56 & \\
\hline $\begin{array}{l}\text { Worsening of } \\
\text { symptoms }\end{array}$ & 0 & 0 & \\
\hline
\end{tabular}

Most common side effect noted with Ormeloxifene was amenorrhoea (9\%), and other side effects being hypomenorrohoea (4\%), GI symptoms (7\%) and headache $(5 \%)$ whereas with Tranexamic acid the observed side effects were head ache $(30 \%)$ and GI symptoms like nausea and vomiting $(10 \%)$, abdominal pain $(20 \%)$, leg cramps $(7 \%)$, arthralgia $(6 \%)$ and fatigue $(5 \%)$.

\section{DISCUSSION}

Menstrual disorders account for most of the Gynaecological referrals. AUB may be defined as any variation from the normal menstrual cycle, and includes changes in regularity and frequency of menses, in duration of flow, or in amount of blood loss. ${ }^{6}$ In the majority of the cases no organic pathology is identified and DUB is considered as diagnosis of exclusion. DUB accounts for almost $50 \%$ of cases of excessive menstruation and is of two types ovulatory (20\%) or anovulatorty $(80 \%) .{ }^{8}$ It reflects a disruption in the normal cyclical pattern of hormonal action on the endometrial lining. Although a number of drugs are available, there is general lack of evidence based approach. Marked variations do exist in practice resulting in continuing uncertainty regarding the most appropriate therapy. Resetting the hypothalamo - pituitary ovarian axis or targeting the final effector pathway would be the best intervention in patients with DUB. Oral contraceptive (OC) pills though effective are associated with few adverse effects. Hence a selective Estrogen receptor modulator with favourable pharmacological profile will be a better option. Ormeloxifene a third generation SERM, antagonises the effects of Estrogen on uterine and breast tissues while having an estrogen agonising effect on vagina, bone, cardiovascular and central nervous systems. The effect of this SERM on the vascular endothelium leads to decrease in blood loss and there by amelioration of symptoms of DUB. Thus, it is beneficial in perimenopausal women as it has no uterine stimulation, prevents bone loss, does not increase the risk of breast cancer, lowers cholesterol levels, and maintains cognitive functions of the brain. ${ }^{9}$ Tranexamic acid is an anti-fibrinolytic inhibitor causing the increased fibrinolytic activity in the endometrium of subjects with DUB. Tranexamic acid has been shown in many studies to be effective in treating DUB. ${ }^{7}$ However, there are no head to head studies comparing these drugs to prove superiority of one over the other. But in the present study the obtained results proved the superiority of Ormeloxifene over Tranexamic acid in the treatment of DUB.

DUB is most common near the beginning and end of woman's reproductive life, but can occur at any time. The perimenopausal transition is associated with a greater occurrence of abnormal uterine bleeding. The incidence of menorrhagia is significantly increased over the age of 40 years. In present study the mean age of patients was 39.45 years.

Chitrangadha et al, Agarwal $\mathrm{N}$ et al reported a $59 \%$ and $61 \%$ reduction in menstrual blood loss with Ormeloxifene but Khare et al noticed $41 \%$ reduction by PBAC method in their studies. ${ }^{8,10,11}$ Studies of Chandra BS et al 2004 using Ormeloxifene in the treatment of DUB showed that the success of the treatment with improvement in heavy flow $(85.7 \%)$ and absence of clots $(85 \%)$ at the end of the treatment. ${ }^{6}$ Study conducted by Fayyaz SS et al to compare Ormeloxifene with Norethisterone showed marked relief of symptoms with significant reduction of blood clots, reduction of Pictorial Blood Assessment Chart (PBAC) scores to an extent of $82 \%$ with Ormeloxifene and $30 \%$ with norethisterone. ${ }^{12-14}$

Trananeximic acid has been shown to be effective in placebo- controlled trails with an overall reduction in the menstrual blood loss 26 to $59 \%$ vs 2 to $8 \%$ from baseline. ${ }^{15}$ Najam $\mathrm{R}$ et al, Kaviani $\mathrm{M}$ et al and Amanda costa et al found $50 \%, 55 \%$ and $51 \%$ reduction in blood loss with Tranexamic acid respectively. ${ }^{8,16-18}$ It is also an 
effective haemostatic agent showing encouraging results in reducing heavy menstrual bleeding. In present study there was found a significant reduction in the menstrual blood loss with both Ormeloxifene and Tranexamic acid, to an extent of $80 \%$ and $64 \%$ respectively, proving Ormeloxifene efficacy over Tranexamic acid.

Presence of clots is an obvious evidence of abnormally excessive bleeding per vaginum. Efficacy of any drug is depicted by increasing reduction in blood loss as well as reduction in the number and size of the menstrual blood clots that can be assessed by PBAC scores. Ormeloxifene competes with Estradiol for binding to cytosal receptors causing prolonged depletion and has long lasting post withdrawal effect. In present study the reduction in the mean PBAC scores with Ormeloxifene (from 278 to 97.6) was found to be significantly more than that of Tranexamic acid (from 261 to 134.5) at 6months of post treatment $(\mathrm{p}<0.0001)$. Overall $77 \%$ of women had a PBAC score $<100$ with Ormeloxifene as compared to only $42 \%$ with Tranexamic acid at the end of the treatment.

The decreased menstrual blood loss was also reflected by prompt improvement in the Hemoglobin levels. Najam R et al found $2.5 \mathrm{~g} \%$ raise in Hemoglobin with Tranexamic acid where as a raise of $1.3 \mathrm{~g} / \mathrm{dl}$ was observed with Ormeloxifene use in study of Khan SA et al. ${ }^{19}$ In present study $\mathrm{Hb}$ raise with Ormeloxifene was $2.45 \mathrm{gm} \%$ and $1.02 \mathrm{gm} \%$ with Tranexamic acid showing in par results with other studies.

Due to prolonged unopposed estrogenic stimulation endometrial thickness is increased in patients with DUB. The endometrial capillaries are abnormal and fragile, hence when it is shed it results in excessive prolonged menstrual blood loss. Ormeloxifene opposes the estrogenic action on endometrium and normalises the ET. Subashchandra B et al reported a reduction in ET from a mean of $11.4 \mathrm{~mm}$ to $7.8 \mathrm{~mm}$, Khan SA et al and Komaram $\mathrm{R}$ et al had an ET reduction of 2.6 and $2.3 \mathrm{~mm}$ respectively with Ormeloxifene. ${ }^{19,20}$ In the present study the mean ET reduced from $10.5 \mathrm{~mm}$ to $6.5 \mathrm{~mm}$ after 6 months therapy with Ormeloxifene whereas with Tranexamic acid the corresponding figures are $9.96 \mathrm{~mm}$ and $7.24 \mathrm{~mm}$ thus proving Ormeloxifene efficacy over Tranexamic acid.

Dysmenorrhoea was reduced in more number of patients with Ormeloxifene probably by reducing uterine congestion. In present study pre-treatment dysmenorrhoea was noted in $28 \%$ of group-A and $30 \%$ in group-B women. The percentages were reduced to $6 \%$ and $14 \%$ in $\mathrm{A}$ and $\mathrm{B}$ groups respectively. Amenorrhoea (9\%) and hypomenorrohoea (5\%) was observed in Ormeloxifene group but it was acceptable to patients who were troubled by menorrhagia and were in perimenopausal period. Amenorrhoea was also observed in other studies by 8 to $43 \%$ of patients. It is usually reversible and needs only reassurance as it may resolve spontaneously after few months of therapy. No pharmacological manipulation to produce menstrual withdrawal will be effective and hence should not be attempted.

Patients assigned to Ormeloxifene group reported a greater subjective improvement in symptom relief and quality of life $(88 \%)$ than those assigned to Tranexamic acid $(56 \%)$.

Although Tranexamic acid is known to reduce menstrual blood loss by $50 \%$ it has not been used widely because of its observed side effects like head ache (30\%)and Gastro intestinal disturbances (10\%), abdominal pain (20\%), leg cramps $(7 \%)$, arthralgia $(6 \%)$ and fatigue $(5 \%)$. It is contraindicated in active thromboembolic disease, severe renal failure and hypersensitivity to the drug. ${ }^{15}$ So, Ormeloxifene when compared to Tranexamic acid is found to be safer with less adverse effects and better patient compliance.

\section{CONCLUSION}

Dysfunctional uterine bleeding is a common gynaecological problem at all ages from menarche to menopause. Majority of the patients respond well to medical therapy. Both Ormeloxifene and Tranexamic acid can be used but Ormeloxifene is found to be superior to Tranexamic acid both in symptom relief, subjective improvement, with fewer side effects, better patient compliance and last but not the least with notable therapeutic efficacy.

Funding: No funding sources Conflict of interest: None declared

Ethical approval: The study was approved by the Institutional Ethics Committee

\section{REFERENCES}

1. Agarwal N, Singh S. The efficacy and safety of ormeloxifene in dysfunctional uterine bleeding. IOSR-JPBS. 2013;5(5):18-21.

2. Dadich S, Agarwal S, Soni M, Jain R. Role of ormeloxifene in medical management of dysfunctional uterine bleeding. Asian J Obstet Gynecol Pract. 2012;6:28-31.

3. Biswas SC, Saha SK, Bag TS, Ghosh Roy SC, Roy AC, Kabiraj SP. Ormeloxifene: A selective estrogen receptor modulator for treatment of dysfunctional menorrhagia. J Obstet Gynecol Ind. 2004 Jan;54(1):56-9.

4. Dhananjay BS, Nanda SK. The Role of Sevista in the Management of Dysfunctional Uterine Bleeding. JCDR. 2013 Jan;7(1):132-4.

5. Bhattacharyya TK, Banerji A. Efficacy of a selective estrogen receptor modulator: ormeloxifene in management of dysfunctional uterine bleeding. SAFOG. 2010 Dec 25;2(3):207-11. 
6. Singh S, Best C, Dunn S, Leyland N, Wolfman WL, Wolfman $\mathrm{W}$ et al. Abnormal uterine bleeding in premenopausal women. J Obstet Gynaecol. Canada. 2013 May 1;35(5):473-5.

7. Higham JM, O'Brien PMS, Shaw RW. Assessment of menstrual blood loss using a pictorial chart. Br J Obstet Gynaecol. 1990;97:734-9.

8. Najam R, Agarwal D, Tyagi R, singh S. Comparison of traneximic acid with a combination of traneximic acid and mefenamic acid in reducing menstrual blood loss in ovulatory dysfunctional uterine bleeding (dub). J Clin Diag Res. 2010;4:3020-5.

9. Agarwal N, Singh S, Singh S, Agarwal M, Manocha P. Comparative evaluation of the efficacy and safety of ormeloxifene and norethisterone in dysfunctional uterine bleeding. Int J Reprod Contracept Obstet Gynecol. 2013;2:194-8.

10. Chitrangada SK, Nag S. A double blinded randomized controlled trial to compare Ormeloxifene and Norethisterone in the treatment of Dysfunctional Uterine Bleeding. IOSR-JDMS. 2014;13(1):52-6.

11. Khare VE, Ghosh GO, Patil PO, Nagar NI. Ormeloxifene $\mathrm{HCl}$ vs. combined oral contraceptive pill in treatment of dub. JEMDS. 2014;4:1026-33.

12. Shahab SF, Jain S, Jain J, Jain U. Ormeloxifene: boon to perimenopausal dysfunctional uterine bleeding (DUB) women in avoiding hysterectomies. Int J Med Sci Edu. 2014 Jan;1(1):21-9.

13. Kaur S, Mittal R, Mittal N. Ormeloxifene: medical management of dysfunctional uterine bleeding. Electronic J Pharmacol Ther. 2014;7:1-4.

14. Jacob KJ, Mini, Deepak AV. A comparative study on the effectiveness of ormeloxifene versus norethisterone in the management of perimenopausal dysfunctional uterine bleeding. IAIM. 2015;2(7):8792.

15. Leminen H, Hurskainen R. Tranexamic acid for the treatment of heavy menstrual bleeding: efficacy and safety. Int J Women's Health. 2012;4:413.

16. Kaviani M, Roozbeh N, Azima S, Amoi S. Comparing the effects of tranexamic acid and mefenamic acid in IUD-induced menorrhagia: randomized controlled trial. IJCBNM. 2013;1(4):216-23.

17. Kost A, Pitney C. Tranexamic acid (Lysteda) for cyclic heavy menstrual bleeding. Am Fam Physic. 2011 Oct 15;84(8):883-6.

18. Chang VW. Does Tranexamic Acid Effectively and Safely Reduce Menstrual Blood Loss (MBL) in Women with Menorrhagia or IUD Induced MBL?. JEMDS. 2014;4:1026-33.

19. Khan SA, Manzoor M, Abdullah A, Banoo A. Efficacy and safety of ormeloxifene in the management of dysfunction uterine bleeding. IOSRJDMS. 2014;13(6):39-42.

20. Ravibabu K, Palla J, Chintada GS. A study of efficacy of ormeloxifene in the pharmacological management of dysfunctional uterine bleeding. J Clini Diagn Res. 2013 Nov;7(11):2534.

Cite this article as: Hymavathi $\mathrm{K}$, Gottipati MD, Prasuna, Sudha V. Ormeloxifene versus Tranexamic acid in dysfunctional uterine bleeding comparative evaluation. Int J Reprod Contracept Obstet Gynecol 2018;7:566-70. 